\title{
LINE $\times$ TESTER ANALYSIS AND ESTIMATING COMBINING ABILITIES FOR YIELD AND SOME YIELD COMPONENTS IN BREAD WHEAT
}

\author{
Deniz ISTIPLILER*, Emre ILKER, Fatma AYKUT TONK, Gizem CIVI, Muzaffer TOSUN \\ Ege University, Faculty of Agriculture, Department of Field Crops, Izmir, TURKEY \\ *Corresponding author: deniz.istipliler@ege.edu.tr
}

Received: 27.01.2015

\begin{abstract}
Estimating of combining ability is useful to assess genotypes and elucidate the nature and magnitude of gene actions involved. Aim of this study was to determine the combining abilities of some wheat genotypes for yield and some yield related traits by using line $\times$ tester mating design. Four advanced wheat lines and one cultivar were used as lines and four wheat genotypes were used as testers. The specific combining ability (SCA) effects were generally found higher than general combining ability effects (GCA) in terms of the agronomic traits studied. As a result, low ratios of $\sigma_{G C A}^{2} / \sigma_{S C A}^{2},\left(\sigma_{D}^{2} / \sigma_{A}^{2}\right)^{1 / 2}$ and low narrow sense heritabilities showed that nonadditive effects controlled the traits studied. Hence, the selection process for superior individual plants should be postponed to further generations like $F_{4}$ or $F_{5}$.
\end{abstract}

Keywords: Bread Wheat, General combining ability, Line $\times$ Tester analysis, Specific combining ability, Triticum aestivum $\mathrm{L}$.

\section{INTRODUCTION}

Bread wheat (Triticum aestivum L.) is the most important cereal crop in the world and plays a crucial role in human and animal nutrition. It is grown more land area worldwide than other field crops and unrivalled in its range of cultivation. In Turkey, it was cultivated on approximately 8 million hectares and 18 and 20 million tons total production is changing every year. Besides, the population in Turkey is increasing day by day, so improving the highly productive wheat genotypes is substantial. This can be achieved by using maximum genetic potential in wheat germplasm.

The knowledge of combining ability is useful to assess differences among the genotypes and also, elucidate the nature and magnitude of gene actions involved. It has an important role to select parents and crosses and it helps to decide breeding methods to be followed to choose desirable individuals (Salgotraet al., 2009).

Plant breeders focus on development of high yielding wheat cultivars by crossing good general combining lines and selecting desirable transgressive segregants from resulting hybrids for grain yield and other traits. Some researchers determined that the general combining ability effects for yield and other characters have played a significant role in selecting parents for grain yield (Kant et al., 2001; Akbar et al., 2009).

Line $\times$ tester analysis is one of the most powerful tools for predicting the general combining ability (GCA) of parents and selecting of suitable parents and crosses with high specific combining ability (SCA) (Rashid et al., 2007). Line $\times$ tester analysis provides information about combining ability effects of genotypes and also, knowledge regarding genetic mechanism controlling yield components. Information of general and specific combining abilities influencing yield and its components has become increasingly important to plant breeders to select appropriate parents for developing hybrid cultivars especially in cross pollinated crops. Many researchers have studied the combining abilities and gene actions of bread wheat hybrid populations by using line $\times$ tester analysis for some traits (Saeed et al., 2001; Krystkowiak et al., 2008; Jain and Sastry, 2012).

The aims of this study were to determine combining abilities of the genotypes, to assess the nature and magnitude of gene actions involved and to predict narrow sense heritability for yield and some yield components in a line $\times$ tester crossing design in bread wheat.

\section{MATERIALS AND METHODS}

The research was carried out at the experimental area of Department of Field Crops, Faculty of Agriculture, Ege University in Izmir during the 2010-2011 and 2011-2012 growing seasons. The soil of the experimental site has a heavy soil structure with clay-silt soil at $0-20 \mathrm{~cm}$ depth and clay-loamy structure at 20-40 cm depth.

Four CIMMYT advanced lines $(129,340,342,47)$ and one registered variety (Sagittario) were used as lines and 
four wheat genotypes (line 3 and 4 from CIMMYT, Basribey and Ziyabey, registered varieties) were used as testers. The testers are well adapted genotypes to this environment also having early maturity. On the other hand, flag leaves of the lines have ability to longer stay green than the testers.

The nine parents were crossed to produce $20 \mathrm{~F}_{1}$ hybrids according to the line $\times$ tester mating design developed by Kempthorne (1957) during 2010-2011 growing season. The 20 crosses and 9 parents were evaluated in Randomized Complete Block Design with three replications during 2011-2012 growing season. In each replication, parents and $\mathrm{F}_{1}$ hybrids were sown in two rows of $1 \mathrm{~m}$ length with a spacing of $20 \mathrm{~cm}$ between rows and 5 $\mathrm{cm}$ between plants. Recommended cultural practices were followed to raise a good crop. $120 \mathrm{~kg} \mathrm{~N}^{-1}$ and $60 \mathrm{~kg} \mathrm{P}$ $\mathrm{ha}^{-1}$ fertilizer were applied equally at sowing time and during the stem elongation period.

Yield and some yield components were measured in parent and $F_{1}$ hybrid plants. Grain yield was measured in grams per row and thousand kernel weight was calculated based on mean value $(\mathrm{g})$ of 4 random samples of 100 kernels from each plot. Other observations were recorded on ten random plants for the characters spike length $(\mathrm{cm})$, plant height $(\mathrm{cm})$ and number of spikes per row then converted to square meter and. Data recorded were subjected to analysis of variance according to Steel and Torrie (1980), to determine significant differences among genotypes. The combining ability and gene effects were studied (Singh and Chaudhary, 1979) using Microsoft Excel. Thet-test was used to test whether the combining ability effects were different from 0 .

\section{RESULTS}

All genotypes that were used in the research showed differences with respect to the traits used in the experiment (Table1). This case showed that there was a significant variation among lines, testers and hybrids, hence it is possible that to calculate the general and specific combining abilities in the population. The lines used in the research exhibited a variation in terms of all studied traits except plant height (Table 1). Also, the interaction between lines and testers were stated as significant for all traits except plant height and spike length. It can be seen that all testers that used in the research generally had similar values in terms of the studied traits (Table2). However, genotype Ziyabey pointed out in terms of high value of spike number for per $\mathrm{m}^{2}$ andgrain yield per row. Furthermore, it was monitored that all lines used in the research have quite different values from each other and there was a big variation between them in terms of the traits measured (Table 2). Otherwise, the hybrids had close values for plant height and spike length traits. However, significant differences were observed among the same hybrids (Table 1).Maximum thousand kernel weight value (49.1 g) was obtained from the combination of $129 \times$ Ziyabey, while minimum value was obtained from the combination of Sagittario $\times 3$ (Table 2). For the thousand kernel weight, there were five combination sexceeded their parental values $(129 \times 4 ; 129 \times$ Basribey, $129 \times$ Ziyabey, $340 \times 3$ and $347 \times 3)$. These data showed that heterotic effects were emerged with high frequency for thousand kernel weight. Spike number for per $\mathrm{m}^{2}$ trait was closely linked with tillering capacity, in this study, minimum spike number for per $\mathrm{m}^{2}$ value was found for the combination of $340 \times$ Ziyabey as $50 \mathrm{pcs} / \mathrm{m}^{2}$, while maximum number was $128 \mathrm{pcs} / \mathrm{m}^{2}$ for the combination of $347 \times$ Basribey. Also,most of the hybrids generally had lower values of spike number for per $\mathrm{m}^{2}$ than the parents (Table 2). For some combinations, the values of grain yield per row were determined as close to parent values and for some combinations it was higher than those of the parents. This situation showed that heterotic effects emerged highly in point of grain yield per row in these hybrids. For grain yield per row, the combinations of $129 \times 3$ and $347 \times$ Basribey had the values of $165.5 \mathrm{~g}$ and $209.6 \mathrm{~g}$, respectively and showed higher performance than tester Ziyabey (151 g) which presented the best performance among all testers. It was found that both of these two combinations had superior dominancy effect for grain yield per row.

Table 1. Mean squares for yield and yield components used in the study.

\begin{tabular}{lllllll}
\hline Source of Variation & DF & $\begin{array}{l}\text { Plant height } \\
(\mathbf{c m})\end{array}$ & $\begin{array}{l}\text { Spike length } \\
(\mathbf{c m})\end{array}$ & $\begin{array}{l}\text { Thousand } \\
\text { kernel } \\
\text { Weight }(\mathbf{g})\end{array}$ & $\begin{array}{l}\text { Spikes } \\
\text { number per } \\
\mathbf{m}^{\mathbf{2}}\end{array}$ & $\begin{array}{l}\text { Yield per } \\
\text { row }(\mathbf{g})\end{array}$ \\
\hline Replication & 2 & $28.1^{* *}$ & $1.9^{*}$ & 0.3 & 61.6 & 20.2 \\
Genotypes & 28 & $81.1^{* *}$ & $2.2^{* *}$ & $72.3^{* *}$ & $1560.8^{* *}$ & $4353.5^{* *}$ \\
Parents & 8 & $169.5^{* *}$ & $3.1^{* *}$ & $84.8^{* *}$ & $1219.5^{* *}$ & $5244.3^{* *}$ \\
Parents and Hybrids & 1 & $203.5^{* *}$ & $36.7^{* *}$ & $184.6^{* *}$ & $962.3^{* *}$ & $29811.6^{* *}$ \\
Hybrids & 19 & 48.3 & $0.9^{* *}$ & $61.1^{* *}$ & $1324.5^{* *}$ & $3954.0^{* *}$ \\
Lines & 4 & 34.8 & $2.2^{* *}$ & $124.0^{* *}$ & $1043.8^{* *}$ & $7087.7^{* *}$ \\
Testers & 3 & 47.5 & 0.6 & $54.8^{* *}$ & $2107.7^{* *}$ & $5753.9^{* *}$ \\
Line $\times$ Tester & 12 & 53.0 & 0.6 & $41.7^{* *}$ & $1222.3^{* *}$ & $2459.4^{* *}$ \\
Error & 56 & 18.7 & 0.4 & 1.1 & 41.5 & 16.7 \\
\hline *:Significant & & & & & \\
\hline
\end{tabular}

\footnotetext{
*:Significant at 1 per cent level, **: Significant at 5 per cent level
} 
Table 2. Mean values of lines, testers and hybrids with respect to studied traits.

\begin{tabular}{|c|c|c|c|c|c|}
\hline Genotypes & $\begin{array}{c}\text { Plant } \\
\text { height } \\
(\mathrm{cm})\end{array}$ & $\begin{array}{c}\text { Spike } \\
\text { length } \\
(\mathrm{cm}) \\
\end{array}$ & $\begin{array}{c}\text { Thousand } \\
\text { kernel } \\
\text { Weight (g) } \\
\end{array}$ & $\begin{array}{c}\text { Spikes } \\
\text { number } \\
\text { per } \mathbf{m}^{2} \\
\end{array}$ & $\begin{array}{l}\text { Yield per } \\
\text { row }(g)\end{array}$ \\
\hline \multicolumn{6}{|l|}{ Lines } \\
\hline 129 & 96.6 & 9.7 & 44.0 & 115 & 146.9 \\
\hline 340 & 95.7 & 10.7 & 34.0 & 89 & 104.7 \\
\hline 342 & 92.3 & 10.3 & 41.1 & 106 & 121.6 \\
\hline 347 & 87.7 & 8.1 & 30.0 & 151 & 39.5 \\
\hline Sagittario & 73.0 & 7.7 & 29.0 & 100 & 32.4 \\
\hline \multicolumn{6}{|l|}{ Testers } \\
\hline 3 & 80.2 & 9.6 & 39.2 & 92 & 104.2 \\
\hline 4 & 86.2 & 10.4 & 42.7 & 106 & 113.2 \\
\hline Basribey & 83.5 & 9.1 & 39.8 & 102 & 120.1 \\
\hline Ziyabey & 85.8 & 9.6 & 38.3 & 135 & 151.0 \\
\hline \multicolumn{6}{|l|}{ Hybrids } \\
\hline $129 \times 3$ & 88.7 & 11.1 & 41.0 & 95 & 165.5 \\
\hline $129 \times 4$ & 84.9 & 11.1 & 45.0 & 92 & 149.4 \\
\hline $129 \times$ Basribey & 88.4 & 10.7 & 46.3 & 98 & 117.6 \\
\hline 129×Ziyabey & 87.6 & 10.5 & 49.1 & 87 & 104.4 \\
\hline $340 \times 3$ & 88.8 & 10.9 & 44.7 & 84 & 148.9 \\
\hline $340 \times 4$ & 91.5 & 11.1 & 42.0 & 114 & 129.6 \\
\hline $340 \times$ Basribey & 89.1 & 11.3 & 41.0 & 76 & 121.2 \\
\hline 340×Ziyabey & 85.1 & 10.1 & 42.7 & 50 & 76.9 \\
\hline $342 \times 3$ & 86.4 & 11.6 & 37.0 & 73 & 121.5 \\
\hline $342 \times 4$ & 89.9 & 10.0 & 36.0 & 107 & 151.2 \\
\hline $342 \times$ Basribey & 76.3 & 10.6 & 39.1 & 71 & 104.1 \\
\hline $342 \times$ Ziyabey & 91.3 & 10.5 & 43.0 & 119 & 101.5 \\
\hline $347 \times 3$ & 89.4 & 9.7 & 45.0 & 76 & 125.2 \\
\hline $347 \times 4$ & 92.5 & 10.5 & 41.4 & 109 & 147.3 \\
\hline $347 \times$ Basribey & 89.1 & 10.3 & 33.3 & 128 & 209.6 \\
\hline 347×Ziyabey & 83.6 & 10.1 & 39.4 & 91 & 123.7 \\
\hline Sagittario $\times 3$ & 84.3 & 9.8 & 31.0 & 62 & 86.2 \\
\hline Sagittario $\times 4$ & 85.4 & 10.4 & 39.2 & 97 & 140.5 \\
\hline Sagittario $\times$ Basribey & 79.7 & 9.8 & 35.8 & 99 & 49.8 \\
\hline Sagittario $\times$ Ziyabey & 89.7 & 9.8 & 43.2 & 54 & 78.6 \\
\hline $\mathbf{L S D}_{0.05}$ & 7.08 & 1.04 & 1.70 & 10.61 & 6.69 \\
\hline
\end{tabular}

General combining ability (GCA) effects of the lines, testers or individual line performances are useful tools for selecting the hybrid parents in cross pollinated plants (Hallauer et al., 1988; Longin et al., 2013). For observed traits, GCA effects of the lines and testers used in the research can be seen at Table 3 . Negligible positive and negative effects were observed between lines and testers for plant height. Besides, it can be seen that one of the testers called Basribey had negative and significant GCA effect. Since, all parents used in the research had the plant height reduced genes, there were remarkable similarity in the plant height measurements among hybrids (Table2). Spike length was found as one of important components of grain yield by various researchers (Kahaliq et.al., 2004; Shahid et al., 2002) and the positive GCA effects were generally observed for spike length. Genotype 129 showed a positive and significant GCA among testers, while genotype 347 and Sagittario had negative and significant GCA effects. This situation showed that in the combinations which include these two genotypes had relatively short spikes (Table 2).All parents except genotype 4 had significant GCA effects for thousand kernel weight. However, it can be realized that negative and significant GCA effects decreasing the thousand kernel weight are more than positive GCA effects. The line 129, which had the highest positive and significant GCA effect, increased the thousand kernel weight in the combinations in which it took a place (Table 2). Spike number for per $\mathrm{m}^{2}$ is one of the most important traits in relation with productive spike number, and it determines the yield of the plant. Therefore, the tester called number 4 and the line called 347 were the most suitable parents for increasing this trait due to their high GCA effects. Saeed et al (2001), specified some bread wheat genotypes based on GCA effects for enhancing the tillering trait. The line number 347 and the tester number 4 significantly increased the grain yield per row for the combinations in which they took a part. It was found that these two genotypes have positive and significant GCA effects. 
Table 3. General combining abilities (GCA) effects of yield and yield components.

\begin{tabular}{|c|c|c|c|c|c|}
\hline Parents & $\begin{array}{l}\text { Plant height } \\
(\mathrm{cm})\end{array}$ & $\begin{array}{l}\text { Spike length } \\
(\mathrm{cm})\end{array}$ & $\begin{array}{l}\text { Thousand } \\
\text { kernel } \\
\text { Weight (g) }\end{array}$ & $\begin{array}{l}\text { Spikes number } \\
\text { per } \mathbf{m}^{2}\end{array}$ & $\begin{array}{l}\text { Yield per row } \\
\text { (g) }\end{array}$ \\
\hline \multicolumn{6}{|l|}{ Lines } \\
\hline 129 & 0.39 & $0.41^{*}$ & $4.59^{* *}$ & 1.28 & $17.83^{\text {*** }}$ \\
\hline 340 & 1.54 & 0.34 & $1.84^{* *}$ & $-7.56^{* *}$ & $-5.06^{* *}$ \\
\hline 342 & -1.14 & 0.17 & $-1.97^{* *}$ & $4.45^{*}$ & $-4.61^{* *}$ \\
\hline 347 & 1.53 & $-0.36^{*}$ & $-1.00^{* *}$ & $12.49^{* *}$ & $27.26^{* *}$ \\
\hline Sagittario & -2.32 & $-0.56^{* *}$ & $-3.46^{* *}$ & $-10.66^{* *}$ & $-35.42^{* *}$ \\
\hline \multicolumn{6}{|l|}{ Testers } \\
\hline 3 & 0.41 & 0.11 & $-1.01^{* *}$ & $-10.31^{* *}$ & $5.27^{* *}$ \\
\hline 4 & 1.72 & 0.12 & -0.05 & $15.57^{* *}$ & $19.42^{* *}$ \\
\hline Basribey & $-2.49^{* *}$ & 0.07 & $-1.63^{* *}$ & 2.81 & $2.51^{*}$ \\
\hline Ziyabey & 0.35 & -0.30 & $2.69^{* *}$ & $-8.07^{* *}$ & $-27.20^{* *}$ \\
\hline
\end{tabular}

*:Significant at 1 per cent level, **: Significant at 5 per cent level

Although, specific combining ability (SCA) is generally suggested for cross pollinated species such as corn or rye (Hallauer and Miranda 1981; Tomerius 2001; Longinet al., 2007; Longinet al., 2013),SCA effects can be used to select homozygous lines that show transgressive segregation. It was observed that $342 \times$ Ziyabey and Sagittario $\times$ Ziyabey combinations had positive and significant SCA effects for plant height (Table 4). Besides that, both combinations had the plant height values that close to each other about $90 \mathrm{~cm}$ which is the appropriate value for the conditions of our region (Table2).

Positive and significant SCA effect for spike length was observed only in the combination of $342 \times 3$ (Table 4). Also, this combination had the highest spike length among the all combinations (Table 2).

Table 4.Spesific combining abilities (SCA) effects of yield and yield components.

\begin{tabular}{|c|c|c|c|c|c|}
\hline Hybrids & $\begin{array}{l}\text { Plant height } \\
\text { (cm) }\end{array}$ & $\begin{array}{l}\text { Spike length } \\
(\mathrm{cm})\end{array}$ & $\begin{array}{l}\text { Thousand } \\
\text { kernel } \\
\text { Weight (g) }\end{array}$ & $\begin{array}{l}\text { Spikes } \\
\text { number per } \\
\text { m }^{2}\end{array}$ & $\begin{array}{l}\text { Yield per } \\
\text { row (g) }\end{array}$ \\
\hline $129 \times 3$ & 0.77 & 0.06 & $-3.34^{\text {** }}$ & $15.98^{* *}$ & $18.20^{* * *}$ \\
\hline $129 \times 4$ & -0.53 & 0.05 & $-4.30^{* *}$ & $-9.90^{* *}$ & $4.05^{*}$ \\
\hline $129 \times$ Basribey & 3.81 & -0.05 & $2.62^{* *}$ & $-8.81^{* * *}$ & $4.32^{*}$ \\
\hline $129 \times$ Ziyabey & -0.26 & -0.10 & $1.02^{*}$ & 5.74 & $-10.47^{* *}$ \\
\hline $340 \times 3$ & -0.26 & -0.01 & $3.15^{* *}$ & $13.14^{* *}$ & $24.45^{* *}$ \\
\hline $340 \times 4$ & 1.11 & 0.08 & -0.55 & $17.60^{* *}$ & $-8.97^{* *}$ \\
\hline $340 \times$ Basribey & 3.01 & 0.37 & 0.03 & $-7.98^{*}$ & -0.47 \\
\hline $340 \times$ Ziyabey & -3.86 & -0.44 & $-2.63^{* *}$ & $-22.77^{* *}$ & $-15.02^{* *}$ \\
\hline $342 \times 3$ & 0.05 & $0.78^{* *}$ & -0.77 & $-9.19^{* *}$ & -3.33 \\
\hline $342 \times 4$ & 2.19 & $-0.76^{* *}$ & $-2.74^{* * *}$ & -1.07 & $12.23^{* *}$ \\
\hline $342 \times$ Basribey & $-7.18^{* *}$ & -0.17 & $1.98^{* * *}$ & $-24.31^{* *}$ & $-18.01^{* *}$ \\
\hline $342 \times$ Ziyabey & $4.93^{*}$ & 0.15 & $1.52^{* *}$ & $34.57^{* *}$ & $9.11^{* *}$ \\
\hline $347 \times 3$ & 0.34 & -0.53 & $6.25^{* *}$ & $-14.57^{* *}$ & $-31.50^{* *}$ \\
\hline $347 \times 4$ & 2.10 & 0.22 & $1.64^{* *}$ & $-7.44^{*}$ & $-23.55^{* *}$ \\
\hline $347 \times$ Basribey & 2.97 & 0.03 & $-4.80^{* *}$ & $24.31^{* *}$ & $55.65^{* *}$ \\
\hline $347 \times$ Ziyabey & $-5.41^{* *}$ & 0.27 & $-3.09^{* *}$ & -2.31 & -0.60 \\
\hline Sagittario $\times 3$ & -0.91 & -0.30 & $-5.29^{* *}$ & -5.36 & $-7.82^{* *}$ \\
\hline sagittoria $\times 4$ & -1.08 & 0.36 & $1.95^{* *}$ & 3.80 & $32.34^{* *}$ \\
\hline Sagittario $\times$ Basribey & -2.61 & -0.19 & 0.17 & $36.79^{* *}$ & $-41.50^{* *}$ \\
\hline Sagittario $\times$ Ziyabey & $4.60^{*}$ & 0.13 & $3.17^{* *}$ & $-15.23^{* *}$ & $16.98^{* *}$ \\
\hline
\end{tabular}

*:Significant at 1 per cent level, **: Significant at 5 per cent level

\section{DISCUSSION}

It can be seen in the Table 4 that there were nine combinations which had positive and significant SCA in terms of thousand kernel weight. The SCA effects were found higher than the GCA effects for this trait (Table 5). Contrary results were reported by Krystkowiak et al., (2008), they studied with 76 wheat hybrids and they found higher GCA effects for thousand kernel weight. Since, test weight is one of the indicators of flour yield (Pomeranz, 1964) and thousand kernel weight positively correlated with test weight (Warechowska, 2013), the wheat genotypes which has high thousand kernel yield are preferred in the flour industry. Hence these nine combinations are preferable for flour industry with their 
thousand kernel weight values around $40 \mathrm{~g}$ and higher. The hybrid number $347 \times 3$ had the best SCA to increase thousand kernel weight (Table 4).

In the case of spike number for per $\mathrm{m}^{2}$ trait, six combinations had positive and significant SCA effects
(Table 4). It was understood that these combinations can generate high amount of productive tillers (Table 2). The number of $347 \times$ Basribey was found as the best hybrid to the number of spike in square meter (Table 4).

Table 5. Genetic component estimations.

\begin{tabular}{|c|c|c|c|c|c|}
\hline & $\begin{array}{l}\text { Plant height } \\
\text { (cm) }\end{array}$ & $\begin{array}{l}\text { Spike length } \\
\text { (cm) }\end{array}$ & $\begin{array}{l}\text { Thousand } \\
\text { kernel } \\
\text { Weight (g) }\end{array}$ & $\begin{array}{l}\text { Spikes } \\
\text { number per } \\
\text { m }^{2}\end{array}$ & $\begin{array}{l}\text { Yield per row } \\
\text { (g) }\end{array}$ \\
\hline $\bar{b}_{G C A}^{2}$ & -0.14 & 0.01 & 0.57 & 2.98 & 43.62 \\
\hline$b_{S C A}^{2}$ & 11.45 & 0.06 & 3.53 & 393.61 & 814.25 \\
\hline$b_{A}^{2}$ & -0.28 & 0.02 & 1.13 & 5.97 & 87.24 \\
\hline$b_{D}^{2^{A}}$ & 11.45 & 0.06 & 13.53 & 393.61 & 814.25 \\
\hline${D^{2}}_{G C A}^{D} / b_{S C A}^{2}$ & 0.01 & 0.19 & 0.04 & 0.01 & 0.05 \\
\hline$\left({b^{2}}_{D} / Б^{2}{ }_{A}\right)^{1} / 2$ & 6.47 & 1.63 & 3.46 & 8.12 & 3.05 \\
\hline$h_{n s}^{2}$ & 0.02 & 0.10 & 0.08 & 0.01 & 0.10 \\
\hline
\end{tabular}

There were nine combinations with respect to grain yield per row which had positive and significant SCA effects (Table 3). It is remarkable that two of them $(347 \times$ Basribey and $129 \times 3$ ) had quite high grain yield per rows (Table 2).

It was found that the lines 125 and 347 and the tester 4 had the high values in terms of the traits studied in the experiment. Furthermore, these lines had enhancer effects for grain yield per rows in the combinations that they took part in. Also, the combinations $129 \times 3,129 \times 4,340 \times 3$, $340 \times 4, \quad 342 \times 4, \quad 347 \times 4$ and Sagittario $\times 4$ came into prominence as promising combinations in terms of the traits evaluated in the research and it can be possible to obtain high yielding lines by carrying these combinations to next generations.

The GCA effects were lower than SCA effects in terms of all traits evaluated in the research in contrast to Titan et al.,(2012). They used 6 wheat lines and seven testers and they tested $42 \mathrm{~F}_{1}$ combinations for two seasons. They observed that SCA effects were generally lower than GCA effects. Besides, Sharma et. al., (2006) and Borghi and Perenzin (1994) stated that $\sigma_{G C A}^{2}$ variance was of greater importance than $\sigma_{S C A}^{2}$ for some traits. The difference in the results reported by researchers may be attributed to differences of parental materials used hybridization and to genotype $\times$ environments. In our results, it was understood that, non additive gene effects were dominant the genetic control of this traits (Table 5). Likewise, dominant genetic variance was found higher than additive variance for all traits. These results showed that $\sigma_{G C A}^{2} / \sigma_{S C A}^{2}$ portion was lower than one and $\left(\sigma_{D}^{2} / \sigma_{A}^{2}\right)$ portion, which is an indicator of dominancy degree, higher than one (Table 5). Hence, it can be seen that non-additive genetic effects are controlling the inheritance of studied traits. It was understood that selection for the traits inherited with this manner should be performed in the further generations like $F_{4}$ or $F_{5}$.Fellahiet al., (2013), reported the importance of non-additive gene action for the plant height, spike length, number of fertile tillers, thousand kernel weight and kernel yield. They recommended that selection of superior plants should be postponed to later generations due to preponderance of non-additive type of gene actions for all studied traits. Similar results of predominance of non-additive gene action for all studied traits have been reported by Vermaet al., (2007) for barley.

The efficiency of the selection is related with the size of narrow sense heritability in the segregating populations. The heritability degrees were found very low for the traits studied in the research (Table 5). Similar results were found by Erkul et. al., (2010). They estimated the genetic effects by using the generation means in six parameters model and low heritability with low genetic advance was found. This situation showed that the additive variance is very low in this population and the selection must be applied in the further generations.

Line $\times$ tester interaction contributed to combinations' variances was found much more than lines and testers, individually. The contributions of the lines to spike length were defined as highest, while to thousand kernel weight and grain yield per row were found closer to line $\times$ tester interaction. The contributions of testers were found lower than those of line $\times$ tester interactions for all traits (Table $6)$. Hence, line $\times$ tester interactions provide much more variation for the appearing of the traits. It is remarkable that hybrid combinations had higher values than their parents with respect to plant height, spike number for per $\mathrm{m}^{2}$ and grain yield per row traits.

The $\sigma_{G C A}^{2} / \sigma_{S C A}^{2}$ ratio varies depending on the allele frequencies between parental populations (Reifet al., 2007; Longinet al., 2013). The lines selected from different gene pools had favorable $\sigma_{G C A}^{2} / \sigma_{S C A}^{2}$ ratio because of their high GCA effects (Labateet al.,1997).In this study, low ratios of $\sigma_{G C A}^{2} / \sigma_{S C A}^{2},\left(\sigma_{D}^{2} / \sigma_{A}^{2}\right)^{1 / 2}$ and low narrow sense heritabilities supported the involvement of non-additive effects with predominance of non-additive type of gene actions (Table 5). Lines and the interaction of line $\times$ testers contributed more to variation of the expression of studied traits. 
Table 6. The contribution rates of lines, testers and line $\times$ tester interaction for hybrid generation $(\%)$.

\begin{tabular}{|c|c|c|c|c|c|}
\hline & $\begin{array}{l}\text { Plant height } \\
(\mathrm{cm})\end{array}$ & $\begin{array}{c}\text { Spike length } \\
(\mathrm{cm})\end{array}$ & $\begin{array}{c}\text { Thousand kernel } \\
\text { Weight (g) }\end{array}$ & Spikes number per $\mathbf{m}^{2}$ & Yield per row (g) \\
\hline Lines & 15.15 & 51.05 & 42.74 & 16.59 & 37.74 \\
\hline Testers & 15.51 & 10.12 & 14.16 & 25.13 & 22.98 \\
\hline Line $\times$ Tester & 69.34 & 38.83 & 43.10 & 58.28 & 39.28 \\
\hline
\end{tabular}

As the conclusion, the line number 129 was good combiner for the spike length, grain yield per row and thousand kernel weight. The line number 347 and the tester number 4 were good combiners for grain yield per row and number of spike in square meter. The number of $347 \times$ Basribey was found as the best hybrid to the number of spike in square meter and grain yield per row. The hybrid number $347 \times 3$ had the best SCA to increase thousand kernel weights. The predominance of nonadditive type of gene actions clearly showed that selection of superior plants should be delayed to $\mathrm{F}_{4}$ or $\mathrm{F}_{5}$ generations.

\section{LITERATURE CITED}

Akbar, M., J. Anwar, M. Hussain, M.H. Qureshi and S. Khan. 2009. Line $\times$ tester analysis in bread wheat (Triticum aestivum L.). J.Agric. Res. 47(1): 411.

Borghi, B.And M. Perenzin.1994.Diallel analysis to predict heterosis and combining ability for grain yield, yield components and bread-making quality in bread wheat ( $T$. aestivum). Theoretical and Applied Genetics 89: 975-981.

Erkul, A., A. Unay and C. Konak. 2010. Inheritance of Yield and Yield Components in a Bread Wheat (Triticum aestivum L.) Cross. Turk J Field Crops, 15:137-140.

Fellahi, Z.E.A., A.Hannachi, H.Bouzerzour and A.Boutekrabt. 2013.Line $\times$ tester mating desing analysis for grain yield and yield related traits in bread wheat (Triticum aestivum L.). International Journal of Agronomy. 2013:9.

Hallauer, A.R. andJ.B. Miranda. 1981. Quantitative genetics in maize breeding. Iowa State University Press, Ames, pp 267298.

Hallauer, A.R.,W.A. Russell andK.R. Lamkey. 1988. Corn breeding. In: Sprague GF, Dudley JW, editors. Corn and corn improvement, 3rd ed. Agron Monogr. 18 ASA, CSSA, SSSA, Madison, WI, pp 469-565.

Jain, S.K. and E.V.D. Sastry. 2012.Heterosis and combining ability for grain yield and its contributing traits in bread wheat (Triticumaestivum L.). Journal of Agriculture and Allied Science 1:17-22.

Kant, L.,V.P. Mani andH.S. Gupta. 2001.Winter $\times$ springwheat hybridization a promising avenue for yield enhancement. Plant Breeding 120:255-259.

Kempthorne, O. 1957.An Introduction to Genetic Statistics, John Wiley \& Sons, New York, NY, USA.

Khaliq, I., N. Parveen, M.A. Chowdhry. Correlation and Path Coefficient Analyses in Bread Wheat International Journal Of Agriculture \& Biology 1560-8530/2004/06-4-633635Krystkowiak,K., T. Adamski, M.Surma and Z. Kaczmarek. 2008. Relationship between phenotypic and genetic diversity of parental genotypes and the specific combining ability and heterosis effects in wheat (Triticum aestivum L.). Euphytica 165: 419-434.
Labate, J.A., K. R. Lamkey, M. Lee and W. L. Woodman. 1997. Molecular genetic diversity after reciprocal recurrent selection in BSSS and BSCB1 maize populations. Crop Sci. 37: 416-423.

Longin, C.F.,M. Gowda, J. Mühleisen, E. Ebmeyer, E. Kazman, R. Schachschneider, J. Schacht M. Kirchhoff, Y. Zhao and J. C. Reif. 2013. Hybrid wheat: quantitative genetic parameters and consequences for the design of breeding programs. Theor. Appl. Genet. 126(11):2791-801.

Longin, C. F. H., H. F. Utz, A. E. Melchinger and J. C. Reif. 2007. Hybrid maize breeding with doubled haploids. II. Optimum type and number of testers in two-stage selection for general combining ability. Theor Appl Genet 114:393402.

Pomeranz, Y. 1964. Wheat Chemistry and Technology (edited), St. Paul, Minnesota. American Association of Cereal Chemists.

Rashid, M.,A.A. Cheema and M. Ashraf. 2007.Line×Tester analysis in basmati rice. Pakistan Journal of Botany. 39(6): 2035-2042.

Reif, J.C., F. Gumpert, S. Fischer and A. E. Melchinger. 2007. Impact of genetic divergence and dominance variance in hybrid populations. Genetics 176: 1931-1934.

Saeed, A., M. A. Chowdhry, N. Saedd, I. Khalıq and M. Z. Johar. 2001. Line×Tester analysis for some morphophysiological traits in bread wheat. International journal of Agriculture \& Biology 3(4):444-447.

Salgotra, R. K., B. B. Gupta and S. Praveen. 2009. Combining ability studies for yield and yield components in Basmati rice. An International Journal on Rice. 46(1):12-16.

Shahid M., F. Mohammad, M. Tahir. 2002. Path coefficient analysis in wheat. Sarhad J. Agrirc. 18: 385-388.

Sharma, H.C., M.K. Dhillan and B. V. S. Reddy. 2006. Expression of resistance to Atherigona soccata in $\mathrm{F}_{1}$ hybrids involving shoot fly-resistant and susceptible cytoplasmic male-sterile and restorer lines of sorghum. Plant breeding 125: 473-477.

Singh, R. K. and B. D. Chaudhary. 1979. Biometrical Methods in Quantitative Genetic Analysis. Second edition, Ed. Kalyani Publishers 191-201., New Delhi, India.

Steel, R. G. D. and J. H. Torrie. 1980. Principles and procedures of statistics. 2nd edition. McGraw Hill Book Company Inc., New York.

Titan, P., V. Meglic and J. Iskra. 2012. Combining ability and heterosis effect in hexaploid wheat group. Genetika 44: 595609.

Tomerius, A.M. 2001. Optimizing the development of seedparent lines in hybrid rye breeding. $\mathrm{PhD}$, University of Hohenheim, Germany.

Verma, A. K., S. R. Vishwakarma and P. K. Singh. 2007. Line x Tester analysis in barley (Hordeum vulgare L.) across environments. Barley Genetics Newsletter 37: 29-33.

Warechowska, M., J. Warechowski, A. Markowska. 2013. Interrelations between selected physical and technological properties of wheat grain. Technical Science, 16(4), 281-290 